\title{
Carcasses at Fixed Locations Host a Higher Diversity of Necrophilous Beetles
}

\author{
Christian von Hoermann ${ }^{1, *(1)}$, Tomáš Lackner ${ }^{1}\left(\mathbb{D}\right.$, David Sommer ${ }^{2,3}$ (), Marco Heurich ${ }^{4,5,6}$, M. Eric Benbow ${ }^{7}$ (1) \\ and Jörg Müller ${ }^{1}$
}

1 Department of Conservation and Research, Bavarian Forest National Park, Freyunger Str. 2, 94481 Grafenau, Germany; Tomas.Lackner@npv-bw.bayern.de (T.L.); Joerg.Mueller@npv-bw.bayern.de (J.M.)

2 Department of Zoology, Faculty of Science, Charles University, Vinicna 7, 12844 Praha, Czech Republic; dejv.sommer@gmail.com

3 Department of Ecology, Faculty of Environmental Sciences, Czech University of Life Sciences in Prague, Kamycka 1176, 16521 Praha, Czech Republic

4 Department of Visitor Management and National Park Monitoring, Bavarian Forest National Park, Freyunger Str. 2, 94481 Grafenau, Germany; Marco.Heurich@npv-bw.bayern.de

5 Chair of Wildlife Ecology and Management, Albert-Ludwigs University of Freiburg, Tennenbacher Str. 4, 79106 Freiburg, Germany

6 Institute for Forest and Wildlife Management, Inland Norway University of Applied Science, NO-2480 Koppang, Norway

7 Department of Entomology, Department of Osteopathic Specialties, AgBioResearch and Ecology, Evolution and Behavior Program, Michigan State University, East Lansing, MI 48824, USA; benbow@msu.edu

* Correspondence: christian.vonhoermann@gmail.com; Tel.: +49-8552-9600-156

Citation: von Hoermann, C.;

Lackner, T.; Sommer, D.; Heurich, M.;

Benbow, M.E.; Müller, J. Carcasses at

Fixed Locations Host a Higher

Diversity of Necrophilous Beetles.

Insects 2021, 12, 412. https://

doi.org/10.3390/insects12050412

Academic Editor: Christos

G. Athanassiou

Received: 12 April 2021

Accepted: 30 April 2021

Published: 4 May 2021

Publisher's Note: MDPI stays neutral with regard to jurisdictional claims in published maps and institutional affiliations.

Copyright: (c) 2021 by the authors. Licensee MDPI, Basel, Switzerland. This article is an open access article distributed under the terms and conditions of the Creative Commons Attribution (CC BY) license (https:/ / creativecommons.org/licenses/by/ $4.0 /)$.
Simple Summary: Whereas vertebrate scavengers have a higher diversity reported at randomly placed carcasses, the drivers of insect diversity on carrion, such as the exposure type (fixed versus random) or the carrion species, are still incompletely understood. We analyzed beetle diversity at differently exposed carcasses in the low-range mountain forest of the Bavarian Forest National Park in Germany. We tested if scavenging beetles, similarly to vertebrate scavengers, show a higher diversity at randomly placed carcasses compared to easily manageable fixed places. Ninety-two beetle species at 29 exposed wildlife carcasses (roe, red deer, and red foxes) were detected. Beetle diversity was higher at fixed locations possessing extended highly nutrient-rich cadaver decomposition islands as important refuges for threatened red-listed species, such as Necrobia violacea (Coleoptera: Cleridae). Particularly noticeable in our insect traps were the following two rare species, the "primitive" carrion beetle Necrophilus subterraneus (Coleoptera: Agyrtidae) and the false clown beetle Sphaerites glabratus (Coleoptera: Sphaeritidae). In Europe, only the species S. glabratus out of the genus Sphaerites is present. This emphasizes the importance of carrion for biodiversity conservation. We clearly show the relevance of leaving and additional providing wildlife carcasses in a dedicated place in protected forests for preserving very rare and threatened beetle species as essential members of the decomposing community.

Abstract: In contrast to other necromass, such as leaves, deadwood, or dung, the drivers of insect biodiversity on carcasses are still incompletely understood. For vertebrate scavengers, a richer community was shown for randomly placed carcasses, due to lower competition. Here we tested if scavenging beetles similarly show a higher diversity at randomly placed carcasses compared to easily manageable fixed places. We sampled 12,879 individuals and 92 species of scavenging beetles attracted to 17 randomly and 12 at fixed places exposed and decomposing carcasses of red deer, roe deer, and red foxes compared to control sites in a low range mountain forest. We used rarefaction-extrapolation curves along the Hill-series to weight diversity from rare to dominant species and indicator species analysis to identify differences between placement types, the decay stage, and carrion species. Beetle diversity decreased from fixed to random locations, becoming increasingly pronounced with weighting of dominant species. In addition, we found only two indicator species for exposure location type, both representative of fixed placement locations and both red listed species, namely Omosita depressa and Necrobia violacea. Furthermore, we identified three 
indicator species of Staphylinidae (Philonthus marginatus and Oxytelus laqueatus) and Scarabaeidae (Melinopterus prodromus) for larger carrion and one geotrupid species Anoplotrupes stercorosus for advanced decomposition stages. Our study shows that necrophilous insect diversity patterns on carcasses over decomposition follow different mechanisms than those of vertebrate scavengers with permanently established carrion islands as important habitats for a diverse and threatened insect fauna.

Keywords: carrion; Coleoptera; decomposition; forest; indicator species; necrobiome; scavenger; succession; trapping

\section{Introduction}

Animal carrion is the most nutrient-rich form of dead organic matter and decomposes at a fast rate [1-3]. These two key qualities of high nutrient concentration and accelerated temporal dynamics make carrion a highly important component of the detritus pool [4]. To obtain a broader recognition of the similarities and differences of decomposing organic matter of any type, Benbow [5] used the term necromass as synonymous with the holistic definition of detritus by Moore [2]. Necromass of any size, shape, and quality (e.g., different diameters and types of deadwood or different carrion types, such as foxes, beavers, red deer, reptiles, or amphibians) dictates many food webs and has a significant bottom-up importance for ecosystem functioning [6-8]. Additionally, necromass forms a resource aggregate for behaviors and interactions among members of the necrobiome, including species of microbes, invertebrates, and vertebrate scavengers [5]. Such complex communities shape whole ecosystems across spatial and temporal scales [9].

However, the drivers of communities in different taxa and how they use and occupy different forms of necromass are still incompletely understood; this is particularly true for carrion in contrast to deadwood (e.g., see References $[10,11])$. Insects are the most speciesrich and abundant animals found on carrion [12]. They deliver a critical ecosystem service by consuming, dispersing, and recycling carrion nutrients [3]. When insects are absent, the rate of decomposition can be significantly delayed $[3,13]$ and can affect microbial processing of carrion $[14,15]$. Consequently, for continuous functioning of ecosystem processes and services, it is of great importance to preserve the biodiversity of the carcass-associated insect fauna and therefore to identify its drivers.

For any species, non-consumptive mortality, such as natural senescence or diseaserelated death, is a natural part of its population dynamics and contributes to the detritus pool and its associated nutrient and energy dynamics [7]. Besides spatially and temporally random distributed death events, the input of vertebrate carrion can also result in spatiotemporally concentrated mass die-off effects. For instance, thousands of kilograms of moose (Alces alces) carcasses per square kilometer in Michigan, USA [16], or millions of kilograms of elephant (Loxodonta africana) cadavers during a mass starvation in Kenya [17] have been reported [18]. Increases in disease, including epidemics, could produce such mass die-off events with disruption effects on the spatial and temporal availability of carrion within the ecosystem $[8,18]$. Understanding the spatial availability of both individual carcasses and mass mortality events is becoming increasingly recognized to have ecosystem function and resource management relevance [18].

Wilmers [19] and Cortés-Avizanda [20] showed that temporal aggregation of carcasses reduced the diversity and evenness of carrion consumption among vertebrate scavengers. However, additional studies are needed to examine and directly manipulate the effects of carrion exposition type (randomly versus predictable fixed locations, e.g., Reference [21]) on invertebrate and vertebrate scavenger community structure. For instance, carrion exposition type was reported as an important driver of avian scavenger diversity [20], where it was shown that randomly placed, unpredictably located cadavers attracted a more diverse (Shannon index) avian scavenger community. The authors suggested that randomly ex- 
posed ungulate cadavers (unpredictable trophic pulses) served as a precondition for the prevention of interspecific competition with a positive effect on scavenger biodiversity [20]. They also suggested that facilitatory processes ("occurrence of positive interspecific relationships within the guild") were responsible for the high detected diversity patterns at randomly exposed carrion through species coexistence $[20,22]$. In predictable conditions, the dominant specialist species can arrive earlier and is able to monopolize the carrion resource [20]. Fitting with this result, Wilmers [19] reported for the Yellowstone National Park a higher vertebrate scavenger diversity at randomly appearing carrion remains caused by wolf kills compared with predictable remains at fixed locations that human hunters established. The reintroduction of wolves in the Yellowstone National Park in 1995 increased the abundance of 13 vertebrate scavenger species by the regular offer of wolf kills [19,23]. Wilmers [19] found a dominance of highly competitive species, such coyotes (Canis latrans) at the spatially and temporally more dispersed wolf kills compared to the spatiotemporally highly aggregated and predictable carrion remains caused by human hunting that were dominated by species with large feeding radii such as ravens and the bald eagle. Given the findings that carcass exposure location and predictability affect vertebrate scavenger communities a central question still exists about if and how invertebrate necrophilous communities may also respond to the spatial availability of vertebrate carrion with potential consequences for the competition between scavengers and necrophagous insects.

For necrophilous invertebrates it has been widely documented that there is a predictable community assembly and succession through decomposition [4,24-29]. This temporal succession theory [24] has a focus on explaining species temporal occurrences [4]. For carrion insects, the succession can be described as following: during the first stage of decomposition, the "fresh stage", the first arriving insects are mostly Calliphoridae and Sarcophagidae flies [30,31]. Their eggs and larvae need moist tissue for successful development [32]. During the next stage, the "bloated stage" (inflated abdomen through gaseous by-products of putrefaction), significant calliphorid maggot masses can be observed [30,31]. In the "post-bloating stage" (=active decay; skin rupture and release of trapped putrefactive gases), not only large feeding masses of fly maggots, but also predatory beetles of the Silphidae, Staphylinidae, and Histeridae families can be observed foraging on fly larvae. At the end of this stage, most of the maggots have left carrion for pupation [30,31]. Late "post-bloating" is preferred by adult dermestid beetles, feeding on the remaining skin and ligamentous tissue [12,33]. In the next two stages, the "advanced decay stage" (most of the flesh has disappeared, and some soft tissue remains in the abdomen) and the "dry remains stage" (only bones, hair, and remains of dried-out skin remain), coleopteran taxa such as Cleridae, Dermestidae, Scarabaeidae, and Trogidae dominate the fauna of the cadaver [31,34-36]. Thus, the community of invertebrates that are attracted to, use and colonize carrion is defined by a changing resource as it is rapidly recycled in the ecosystem. In this study, we hypothesized that the type (i.e., vertebrate species), position, and predictability of these resources in a forest ecosystem will shape the necrophagous insect communities that occupy and use it during decomposition. We predicted that randomly placed carcasses would attract and reflect a more diverse insect community compared to predictable carcass exposure locations, similar to that reported for vertebrates. We further investigated the impact of the decomposition stage and carcass biomass on diversity, as well as all on characteristic species.

\section{Materials and Methods}

\subsection{Study Site Description}

Cadaver exposition and associated insect trapping were conducted throughout the Bavarian Forest National Park (BFNP) in Eastern Bavaria, Germany. Together with the Šumava National Park, Czech Republic, the BFNP forms the Bohemian Forest Ecosystem, one of the largest strictly protected woodlands of Central Europe. A humid and cold continental climate is prevailing with some maritime influence from the West. The annual air temperature ranges between 3.9 and $8.6{ }^{\circ} \mathrm{C}$. The annual precipitation varies from 
$400 \mathrm{~mm}$ up to $2500 \mathrm{~mm}$ and elevation ranges from $370 \mathrm{~m}$ above sea level (a.s.l.) in the valleys up to $1456 \mathrm{~m}$ a.s.l. along the mountain ridges. From October to May, a permanent snow cover lasts up to 7 months on the mountain peaks and up to 5 months from November to April in the valleys. The forested part of the BFNP amounts to $98 \%$ and $2 \%$ are open raised bogs, water bodies, abandoned mountain pastures, or boulder fields [37]. The forested area is mostly covered by mixed mountain forest, consisting of Norway spruce (Picea abies), Silver fir (Abies alba) and European beech (Fagus sylvatica), and mountain spruce forest. In high montane elevation, above the grass and often spruce-rich mixed forests, are Hercynian mountain forests (Piceion) dominated by Norway spruce and accompanied by sycamore (Acer pseudoplatanus) and mountain ash (Sorbus aucuparia) [38]. Through cold air flowing down the mountain slopes and accumulating in damp valley basins, ground frosts are possible in these zones even in summer months. The large mammal species pool (as an omnipresent source of carrion) includes the herbivores, red deer (Cervus elaphus) and roe deer (Capreolus capreolus); the omnivore wild boar (Sus scrofa); and the carnivores, Eurasian lynx (Lynx lynx) and the gray wolf (Canis lupus). The most abundant carcass-visiting mesopredators are the red fox (Vulpes vulpes) and the pine marten (Martes martes) [21]. As part of the invertebrate species pool, more than 2000 beetle species were documented [39].

\subsection{Experimental design}

\subsubsection{Wildlife Carcass Exposure}

Carcasses of 6 red deer, 18 roe deer, and 5 foxes were placed in the BFNP over the months of June to November 2018 at four different fixed locations (a total of 12 carcasses) and 17 different random sites (a total of 17 carcasses) as follows (Supplementary Materials Table S1). On the first Tuesday of every month, two deer carcasses were placed on two of the four fixed locations and 2 up to 4 carcasses ( 2 deer and in addition (if available) 1 or 2 foxes; Supplementary Materials Table S1) were placed once on each of the overall 17 random sites. In each subsequent month, the other two fixed locations were fitted with carrion in an alternating way. Carcass numbers and exposed species per month differed because of irregularities in carcass supply. Roe deer and fox cadavers were obtained from wildlife-vehicle collisions that randomly took place at National Park roads, whereas red deer carcasses originated from wildlife control measures in the National Park [40]. The carcasses ranged from freshly killed to previously frozen at $-20{ }^{\circ} \mathrm{C}$ and were all defrosted for four days to represent the fresh stage of decomposition at the time of exposition (day 0). Carrion weight ranged from 4.7 (single fox carcass) to 110 (single red deer carcass) kilograms (Supplementary Materials Table S1). One hind limb of each deer and fox carcass was fixed with a cable tied to a wooden stick. After total carcass depletion, bones and remains of furs stayed on site. We mounted data loggers (Thermochron iButton, Whitewater, WI, USA) at each carrion exposition site to record the temperature and humidity of the carrion microhabitat every 30 min during the whole exposition period of 30 days. In parallel to the carrion exposition, a total of 16 control sites ( 4 activated per month; Supplementary Materials Table S1) comprising 12 control sites to the corresponding random locations and four control sites of the same type (differing only in location) to the corresponding fixed locations were installed. On each single control site without a carcass, two pitfall traps (see next subheading for more details) and one camera trap were installed. Controls were needed to capture the prevailing and not necessarily carcass-associated insect and vertebrate fauna of the habitat. All carrion exposition and control sites were arranged in half-open mixed montane forest stands and were sufficiently spaced at a minimum distance of $1000 \mathrm{~m}$ to avoid cross interactions among individual cadavers. A minimum distance between sampling plots of $200 \mathrm{~m}$ is already sufficient to achieve spatial independency in assemblages of flying insects [41,42]. Site elevation ranged from 643 to $1126 \mathrm{~m}$ above sea level (Supplementary Materials Table S1). 


\subsubsection{Pitfall Trap Installation and Beetle Sampling}

Two pitfall traps for trapping of necrophilous insects were installed directly at each wildlife carcass. One pitfall trap was mounted adjacent to the mouth of the carcass, with the other one being adjacent to its anus. Consequently, two important settlement areas (head and anus) for cadaver-inhabiting insects were covered [43]. For pitfall trapping, two ground-level plastic cups were stacked inside each other (half-liter PLA cups; diameter, 95 mm; height, 151.2 mm; Huhtamaki Foodservice GmbH, Alf/Mosel, Germany). For the reduction of surface tension, the inner cup was filled with an odorless soapy solution (one droplet of detergent, Klar EcoSensitive, AlmaWin, Winterbach, Germany). Each single trap was equipped with a rain cover (constructed at BFNP) to avoid overflow. The same procedure was used at the control sites without carcasses. For comparison purposes, the distance of the two control pitfall traps at one single capture site corresponded to the distance between head and anus of the exposed respective wildlife species. A total of 7 trap content collection events per exposed carcass and control were conducted over the decomposition period at 2, 4, 6, 9, 16, 23, and 30 days after day 0 of exposure [36,44]. All distinct decomposition stages, based on large-scale succession data in the literature [28,36,44,45], were covered by these sampling intervals. To guarantee a constant sample period for each trapping event, the pitfall traps were opened by removing the lid (PLA dome-covers for smoothie cups; diameter, $95 \mathrm{~mm}$; Huhtamaki Foodservice GmbH, Alf/Mosel, Germany) at $48 \mathrm{~h}$ before content collection. Consequently, each beetle sampling event lasted $48 \mathrm{~h}$. All exposed wildlife cadavers were photo-documented at each trap-emptying event for later morphological assessment and classification of decomposition stages [33].

Immediately after each trap-emptying event, we transferred all collected insect individuals into 70\% ethanol (VWR International GmbH, Darmstadt, Germany) for later presorting into the following beetle groups: Silphidae, Staphylinidae, Scarabaeidae, Histeridae, Dermestidae, and "Coleoptera rest" (all other beetle taxonomic groups) and subsequent species identification by external specialists. From these families, all individuals were identified to species level and stored at the BFNP. For any single trapping event, all data for the two traps were pooled (no separate consideration of mouth and anus traps in later analyses). The same procedure was conducted for the control sites. The sampling campaign resulted in a total of 343 sample units (203 carrion sample units and 140 control sample units). All 343 samples from 37 plots formed the basis for subsequent statistical analyses.

\subsection{Statistics}

All analyses were conducted in R and R Studio versions 4.0.3 [46]. To test the effects of carcass exposure location (randomly and fixed location) and controls on overall abundance of obligate, facultative necrophilous, and guest beetles, Poisson-GLM models (including multcomp for post hoc multiple comparison testing) were applied.

To compare species diversity between the exposition types (random versus fixed location) with respect to early, intermediate, and late decay successional stages, we used an individual based rarefaction-extrapolation approach to estimate necrophilous beetle diversity accounting for sampling effort. Hill [47] unified different diversity indices in the Hill numbers, using an increasing weighting from rare to dominant species. We used this approach and compared diversities for three values of $\mathrm{q}(\mathrm{q}=0$, species richness; $q=1$, exponential of Shannon's entropy index; $q=2$, inverse of Simpson's concentration index). Computations were implemented with the iNEXT package $[48,49]$. Finally, we applied indicator species analysis $(p<0.05)$ to identify obligate and facultative necrophilous species characteristics for both carrion placements (random versus fixed location) and with respect to early, intermediate, and late decay successional stages and carrion species (small, intermediate, and high carrion biomass), using the multipatt function in the add-on package indicspecies [50]. 


\section{Results}

In total, we identified 92 beetle species from 12,879 individuals on 29 exposed wildlife cadavers (Table 1 and Figure 1), compared to control locations that had only 23 species and 92 beetle individuals (Table 1 ).

Table 1. Beetle species with number of individuals (Indiv) in dependency of the exposition type (random sites, fixed locations, and controls).

\begin{tabular}{|c|c|c|c|c|c|}
\hline Species & Family & Ecology & Indiv (Random) & Indiv (Fixed) & Indiv (Controls) \\
\hline Saprinus semistriatus (L. G. Scriba, 1790) & Histeridae & fac & 165 & 427 & 3 \\
\hline Margarinotus striola (C. Sahlb., 1819) & Histeridae & $\mathrm{fac}$ & 145 & 157 & 6 \\
\hline Margarinotus brunneus (F., 1775) & Histeridae & fac & 0 & 1 & 0 \\
\hline Hister unicolor L., 1758 & Histeridae & fac & 1 & 0 & 0 \\
\hline Sphaerites glabratus $(F ., 1792)$ & Sphaeritidae & fac & 6 & 3 & 0 \\
\hline Nicrophorus humator (Gled., 1767) & Silphidae & obl & 68 & 58 & 0 \\
\hline Nicrophorus investigator Zett., 1824 & Silphidae & obl & 100 & 70 & 0 \\
\hline Nicrophorus interruptus Steph., 1830 & Silphidae & obl & 6 & 1 & 0 \\
\hline Nicrophorus vespilloides Herbst, 1783 & Silphidae & obl & 686 & 614 & 0 \\
\hline Nicrophorus vespillo (L., 1758) & Silphidae & obl & 4 & 3 & 0 \\
\hline Necrodes littoralis (L., 1758) & Silphidae & obl & 328 & 268 & 0 \\
\hline Thanatophilus rugosus (L., 1758) & Silphidae & obl & 26 & 101 & 0 \\
\hline Thanatophilus sinuatus (F., 1775) & Silphidae & obl & 439 & 976 & 0 \\
\hline Oiceoptoma thoracicum $(L ., 1758)$ & Silphidae & obl & 290 & 528 & 0 \\
\hline Necrophilus subterraneus (Dahl, 1807) & Agyrtidae & $\mathrm{fac}$ & 1 & 7 & 0 \\
\hline Agyrtes castaneus (F., 1792) & Agyrtidae & obl & 0 & 0 & 1 \\
\hline Sciodrepoides watsoni (Spence, 1813) & Leiodidae & obl & 1 & 0 & 0 \\
\hline Sciodrepoides fumatus (Spence, 1813) & Leiodidae & obl & 4 & 0 & 0 \\
\hline Catops kirbyi (Spence, 1813) & Leiodidae & obl & 1 & 1 & 0 \\
\hline Apocatops nigrita (Er., 1837) & Leiodidae & obl & 1 & 0 & 0 \\
\hline Megarthrus depressus sensu FHL Bd 4-15, & Staphylinidae & $\mathrm{fac}$ & 0 & 1 & 0 \\
\hline Proteinus brachypterus (F., 1792) & Staphylinidae & $\mathrm{fac}$ & 0 & 3 & 0 \\
\hline Omalium rivulare (Payk., 1789) & Staphylinidae & $\mathrm{fac}$ & 42 & 24 & 2 \\
\hline Omalium septentrionis C. Thoms., 1857 & Staphylinidae & fac & 71 & 87 & 1 \\
\hline Omalium rugatum Muls. et Rey, 1880 & Staphylinidae & $\mathrm{fac}$ & 0 & 1 & 0 \\
\hline Anthobium melanocephalum (Ill., 1794) & Staphylinidae & fac & 0 & 7 & 0 \\
\hline Arpedium quadrum (Grav., 1806) & Staphylinidae & $\mathrm{fac}$ & 14 & 5 & 4 \\
\hline Oxytelus laqueatus (Marsh., 1802) & Staphylinidae & $\mathrm{fac}$ & 25 & 4 & 0 \\
\hline Anotylus rugosus (F., 1775) & Staphylinidae & $\mathrm{fac}$ & 0 & 1 & 0 \\
\hline Anotylus sculpturatus (Grav., 1806) & Staphylinidae & fac & 1 & 4 & 0 \\
\hline Stenus clavicornis (Scop., 1763) & Staphylinidae & guest & 0 & 1 & 0 \\
\hline Rugilus rufipes (Germar, 1836) & Staphylinidae & fac & 6 & 10 & 1 \\
\hline Rugilus mixtus Lohse, 1956 & Staphylinidae & fac & 0 & 1 & 0 \\
\hline Xantholinus tricolor $(F ., 1787)$ & Staphylinidae & $\mathrm{fac}$ & 0 & 1 & 0 \\
\hline Xantholinus longiventris Heer, 1839 & Staphylinidae & $\mathrm{fac}$ & 3 & 2 & 1 \\
\hline Atrecus affinis (Payk., 1789) & Staphylinidae & $\mathrm{fac}$ & 0 & 1 & 0 \\
\hline Philonthus laevicollis (Lacord., 1835) & Staphylinidae & fac & 12 & 7 & 0 \\
\hline Philonthus rufipes (Steph., 1832) & Staphylinidae & $\mathrm{fac}$ & 13 & 11 & 0 \\
\hline Philonthus carbonarius Grav., 1802 & Staphylinidae & $\mathrm{fac}$ & 266 & 102 & 0 \\
\hline Philonthus addendus Sharp, 1867 & Staphylinidae & fac & 1 & 0 & 0 \\
\hline Philonthus pseudovarians A. Strand, 1941 & Staphylinidae & fac & 0 & 4 & 0 \\
\hline Philonthus splendens (F., 1792) & Staphylinidae & $\mathrm{fac}$ & 3 & 0 & 1 \\
\hline Philonthus fimetarius (Grav., 1802) & Staphylinidae & $\mathrm{fac}$ & 143 & 79 & 1 \\
\hline Philonthus marginatus (O. F. Müller, 1764) & Staphylinidae & $\mathrm{fac}$ & 18 & 10 & 0 \\
\hline Creophilus maxillosus (L., 1758) & Staphylinidae & fac & 137 & 172 & 0 \\
\hline Ontholestes tessellatus (Geoffr., 1785) & Staphylinidae & $\mathrm{fac}$ & 19 & 17 & 0 \\
\hline Ontholestes murinus (L., 1758) & Staphylinidae & obl & 0 & 3 & 0 \\
\hline Dinothenarus fossor (Scop., 1771) & Staphylinidae & guest & 0 & 0 & 4 \\
\hline Ocypus olens (O. F. Müller, 1764) & Staphylinidae & fac & 0 & 0 & 1 \\
\hline Quedius cinctus (Payk., 1790) & Staphylinidae & fac & 55 & 18 & 0 \\
\hline Lordithon trinotatus (Er., 1839) & Staphylinidae & fac & 32 & 3 & 11 \\
\hline Tachyporus pusillus Grav., 1806 & Staphylinidae & $\mathrm{fac}$ & 1 & 0 & 0 \\
\hline Tachinus pallipes Grav., 1806 & Staphylinidae & $\mathrm{fac}$ & 471 & 81 & 2 \\
\hline Atheta excellens (Kr., 1856) & Staphylinidae & fac & 1 & 0 & 0 \\
\hline Atheta longicornis (Grav., 1802) & Staphylinidae & fac & 0 & 1 & 0 \\
\hline Acrotona parvula (Mannerh., 1830) & Staphylinidae & fac & 1 & 0 & 0 \\
\hline Oxypoda opaca (Grav., 1802) & Staphylinidae & $\mathrm{fac}$ & 0 & 1 & 0 \\
\hline Oxypoda formosa Kr., 1856 & Staphylinidae & $\mathrm{fac}$ & 1 & 0 & 0 \\
\hline Aleochara curtula (Goeze, 1777) & Staphylinidae & obl & 1 & 2 & 0 \\
\hline
\end{tabular}


Table 1. Cont.

\begin{tabular}{|c|c|c|c|c|c|}
\hline Species & Family & Ecology & Indiv (Random) & Indiv (Fixed) & Indiv (Controls) \\
\hline Lampyris noctiluca $($ L., 1767$)$ & Lampyridae & fac & 1 & 0 & 0 \\
\hline Necrobia violacea (L., 1758) & Cleridae & obl & 1 & 44 & 0 \\
\hline Necrobia rufipes (DeGeer, 1775) & Cleridae & obl & 2 & 3 & 0 \\
\hline Dermestes murinus L., 1758 & Dermestidae & obl & 2 & 1 & 0 \\
\hline Dermestes laniarius Ill., 1801 & Dermestidae & obl & 0 & 1 & 0 \\
\hline Byrrhus pilula (L., 1758) & Byrrhidae & guest & 0 & 0 & 4 \\
\hline Byrrhus glabratus Heer, 1841 & Byrrhidae & guest & 0 & 0 & 1 \\
\hline Omosita depressa (L., 1758) & Nitidulidae & obl & 14 & 314 & 0 \\
\hline Cychramus variegatus (Herbst, 1792) & Nitidulidae & guest & 2 & 0 & 0 \\
\hline Mycetina cruciata (Schaller, 1783) & Endomychidae & guest & 1 & 0 & 0 \\
\hline Anaspis rufilabris (Gyll., 1827) & Scraptiidae & fac & 1 & 0 & 0 \\
\hline Corticeus unicolor Pill. et Mitt., 1783 & Tenebrionidae & guest & 0 & 0 & 1 \\
\hline Trox scaber $(L ., 1767)$ & Trogidae & obl & 0 & 1 & 0 \\
\hline Geotrupes stercorarius (L., 1758) & Geotrupidae & fac & 0 & 1 & 0 \\
\hline $\begin{array}{l}\text { Anoplotrupes stercorosus (Hartmann in L. G. } \\
\text { Scriba, 1791) }\end{array}$ & Geotrupidae & $\mathrm{fac}$ & 3625 & 1086 & 41 \\
\hline Teuchestes fossor (L., 1758) & Scarabaeidae & fac & 0 & 1 & 0 \\
\hline Ammoecius brevis (Er., 1848) & Scarabaeidae & $\mathrm{fac}$ & 4 & 8 & 0 \\
\hline Acrossus rufipes (L., 1758) & Scarabaeidae & fac & 45 & 54 & 0 \\
\hline Acrossus luridus (F., 1775) & Scarabaeidae & $\mathrm{fac}$ & 1 & 0 & 0 \\
\hline Acrossus depressus (Kugel., 1792) & Scarabaeidae & $\mathrm{fac}$ & 42 & 10 & 0 \\
\hline Limarus maculatus (Sturm, 1800) & Scarabaeidae & $\mathrm{fac}$ & 12 & 3 & 0 \\
\hline Volinus sticticus (Panzer, 1798) & Scarabaeidae & fac & 0 & 1 & 0 \\
\hline Nimbus contaminatus (Herbst, 1783) & Scarabaeidae & $\mathrm{fac}$ & 3 & 0 & 0 \\
\hline Melinopterus sphacelatus (Panzer, 1798) & Scarabaeidae & $\mathrm{fac}$ & 0 & 2 & 0 \\
\hline Melinopterus prodromus (Brahm, 1790) & Scarabaeidae & fac & 1 & 8 & 0 \\
\hline Planolinus fasciatus (Olivier, 1789) & Scarabaeidae & $\mathrm{fac}$ & 1 & 0 & 0 \\
\hline Calamosternus granarius (L., 1767) & Scarabaeidae & fac & 0 & 1 & 0 \\
\hline Serica brunnea $(L ., 1758)$ & Scarabaeidae & guest & 0 & 0 & 1 \\
\hline Ips typographus (L., 1758) & Scolytidae & guest & 0 & 0 & 1 \\
\hline Otiorhynchus scaber (L., 1758) & Curculionidae & guest & 1 & 0 & 0 \\
\hline Phyllobius arborator (Herbst, 1797) & Curculionidae & guest & 0 & 1 & 1 \\
\hline Hylobius abietis (L., 1758) & Curculionidae & guest & 0 & 0 & 2 \\
\hline Plinthus tischeri Germar, 1824 & Curculionidae & guest & 0 & 0 & 1 \\
\hline
\end{tabular}

In Ecology, "obl" stands for obligatory necrophilous, "fac" stands for facultative necrophilous, and "guest" designates random visitors (non-necrophilous species) at carrion exposition sites.

There was a noticeable variation in rank abundance, numbers of individuals, and beetle species on carrion between the exposition sites (Figure 2).

Rank-abundance distribution at fixed locations was more balanced (more flattened rank abundance curve) compared to random sites (steeper curve progression), showing a higher species richness and no striking abundance of single species at fixed locations (Figure 2). Insect numbers ranged from 0 to 1213, collected from one single random location with a $7 \mathrm{~kg}$ fox cadaver in November 2018 and a $19.1 \mathrm{~kg}$ roe deer cadaver site (fixed location) in June 2018, respectively. The number of necrophilous beetle species per site varied from 0 at a single random site with the same $7 \mathrm{~kg}$ fox cadaver in November 2018 to 84 species at a random site with a $21 \mathrm{~kg}$ roe deer cadaver in August 2018.

Carcass at both random and fixed locations attracted significantly more necrophilous beetles than control sites (Poisson-GLMM with Tukey contrasts $(p<0.05)$ : Randomly versus Fixed location, $z=0.684, p=0.773$; Randomly versus Control, $z=-7.326, p<0.001$; Fixed location versus Control, $z=-7.386, p<0.001$; Figure 1). Rarefaction-extrapolation analyses revealed higher beetle diversity at fixed than random places, increasingly pronounced with increasing weighting of dominant species along the three Hill numbers (well-separated confidence intervals for Simpson diversity $(\mathrm{q}=2$ ); Figure 3 and Supplementary Materials Table S2). 


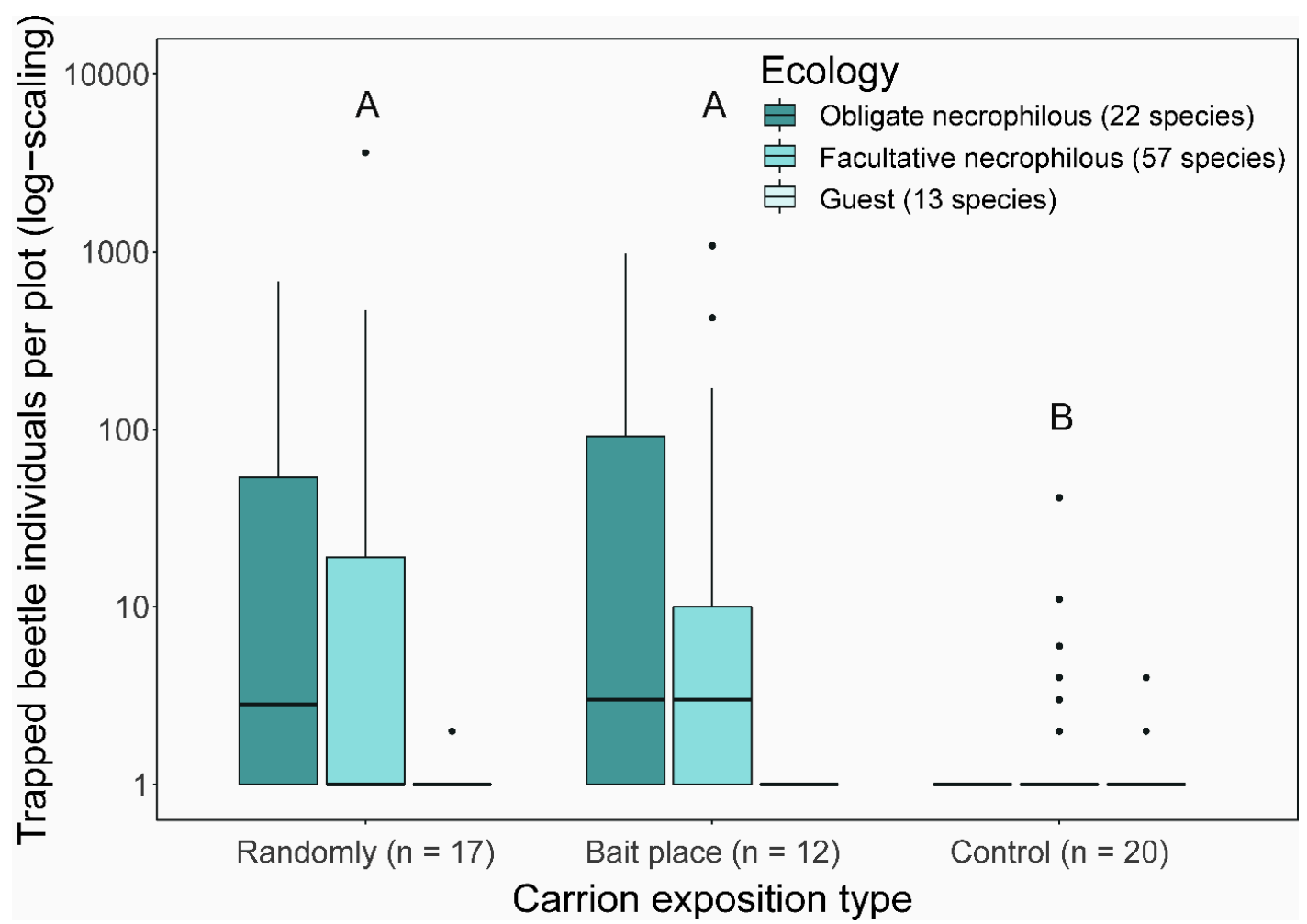

Figure 1. Median abundance of trapped obligate, facultative necrophilous, and guest beetle individuals per plot for each exposition type. The different letters indicate significant differences between exposition types (Poisson-GLMM with Tukey contrasts $(p<0.05) ; \mathrm{n}=$ number of treatments).

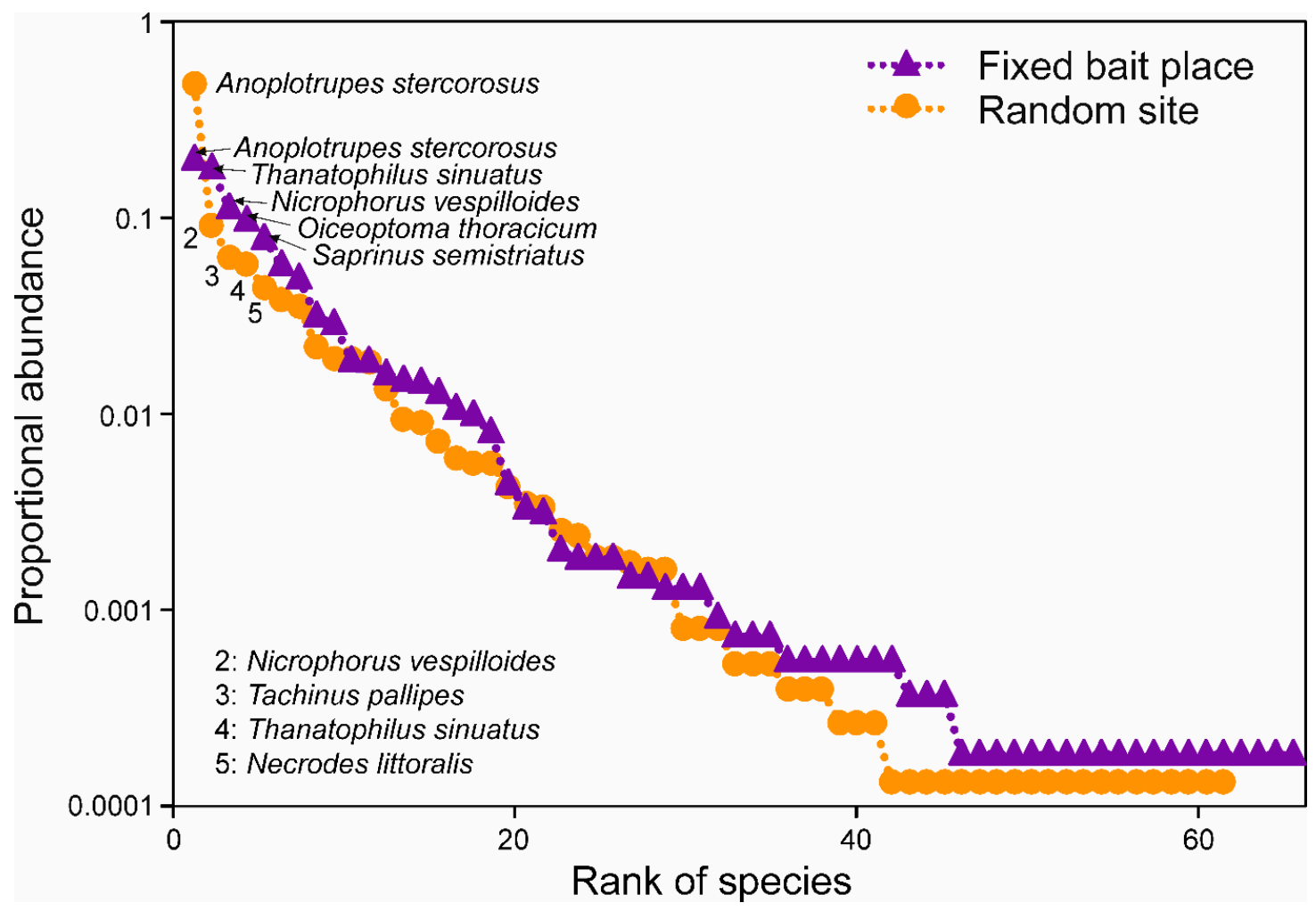

Figure 2. Rank-abundance curves of necrophilous beetles at random and fixed locations. Violet triangles, visitors at fixed locations; orange circles, visitors at random sites. The five most abundant species are labeled, respectively. For information regarding beetle families and -ecology (facul-tative necrophilous or obligate necrophilous) refer to Table 1. 

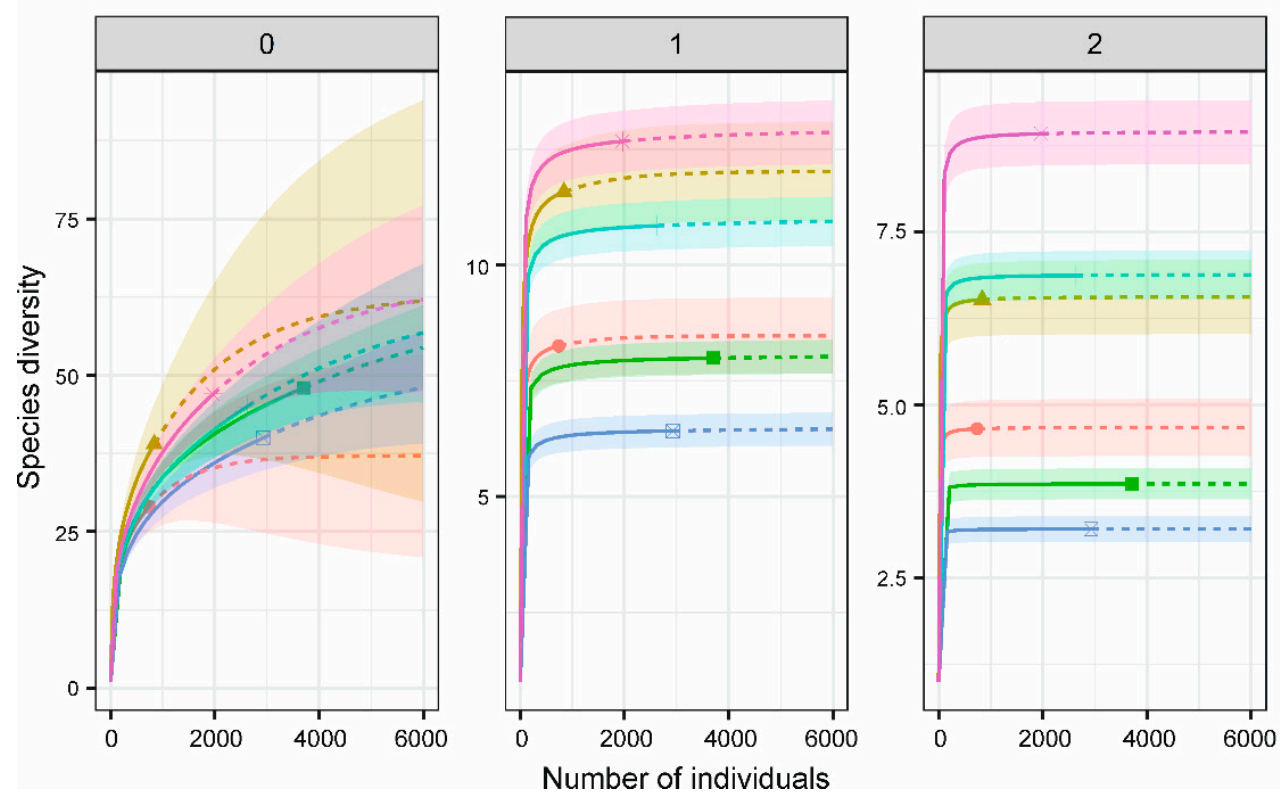

Succession_exposure

Early_intensive

Middle_intensive

Late_intensive

Early_extensive

Middle_extensive

Late_extensive

- Interpolated

- Extrapolated

Figure 3. Individual-based rarefaction and extrapolation of beetle diversity for the two different treatments in combination with carcass succession stages, along with $95 \%$ unconditional confidence intervals. Species diversity was estimated for Hill numbers: $q=0$ (species richness, left panel), $q=1$ (exponential of Shannon's entropy index, middle panel), and $q=2$ (inverse of Simpson's concentration index, right panel). Symbols represent the total number of reference individuals. Rarefaction curves in solid lines; extrapolation curves in dotted lines. Extensive $=$ random site; intensive $=$ fixed location. Early $=$ fresh, middle $=$ bloated and active decay, and late = advanced decay and dry remains succession stages. In transparent shading, $95 \%$ confidence intervals.

We detected the highest diversity of common $(q=1)$ and dominant $(q=2)$ beetle species during middle decay stages (bloated, active decay) at fixed locations (Figure 3 and Supplementary Materials Table S2), but the lowest diversity was in middle decay stage carcasses at random sites, which was valid for Hill-numbers 1 (common beetle species) and 2 (dominant beetle species) (Figure 3 and Supplementary Materials Table S2). For rare species, the highest diversity was during fresh carcass decay stage at fixed locations, whereas the lowest diversity was found during fresh stage at random sites (Figure 3, $q=0$ ). However, confidence intervals of the rarefaction and extrapolation curves highly overlapped for species richness ( $q=0$; Figure 3 and Supplementary Materials Table S2), indicating a similar estimated diversity of rare beetle species across treatment types and decay stages.

Indicator species analysis revealed two indicator species for exposition site, both for fixed locations (Supplementary Materials Table S3) and both were red listed species Omosita depressa $($ IndVal $=0.662 ; p=0.004)$ and Necrobia violacea $($ IndVal $=0.540 ; p=0.004)$ [51].

Two indicator species of Staphylinidae (Philonthus marginatus; IndVal $=0.629 ; p=0.011$ and Oxytelus laqueatus; IndVal $=0.568 ; p=0.017$ ) were detected for high carcass mass (heavy red deer carrion) at random sites (Figure 4 and Supplementary Materials Table S4) and one indicator species of Scarabaeidae (Melinopterus prodromus; IndVal $=0.545 ; p=0.012$ ) at fixed locations (Figure 4 and Supplementary Materials Table S5). 


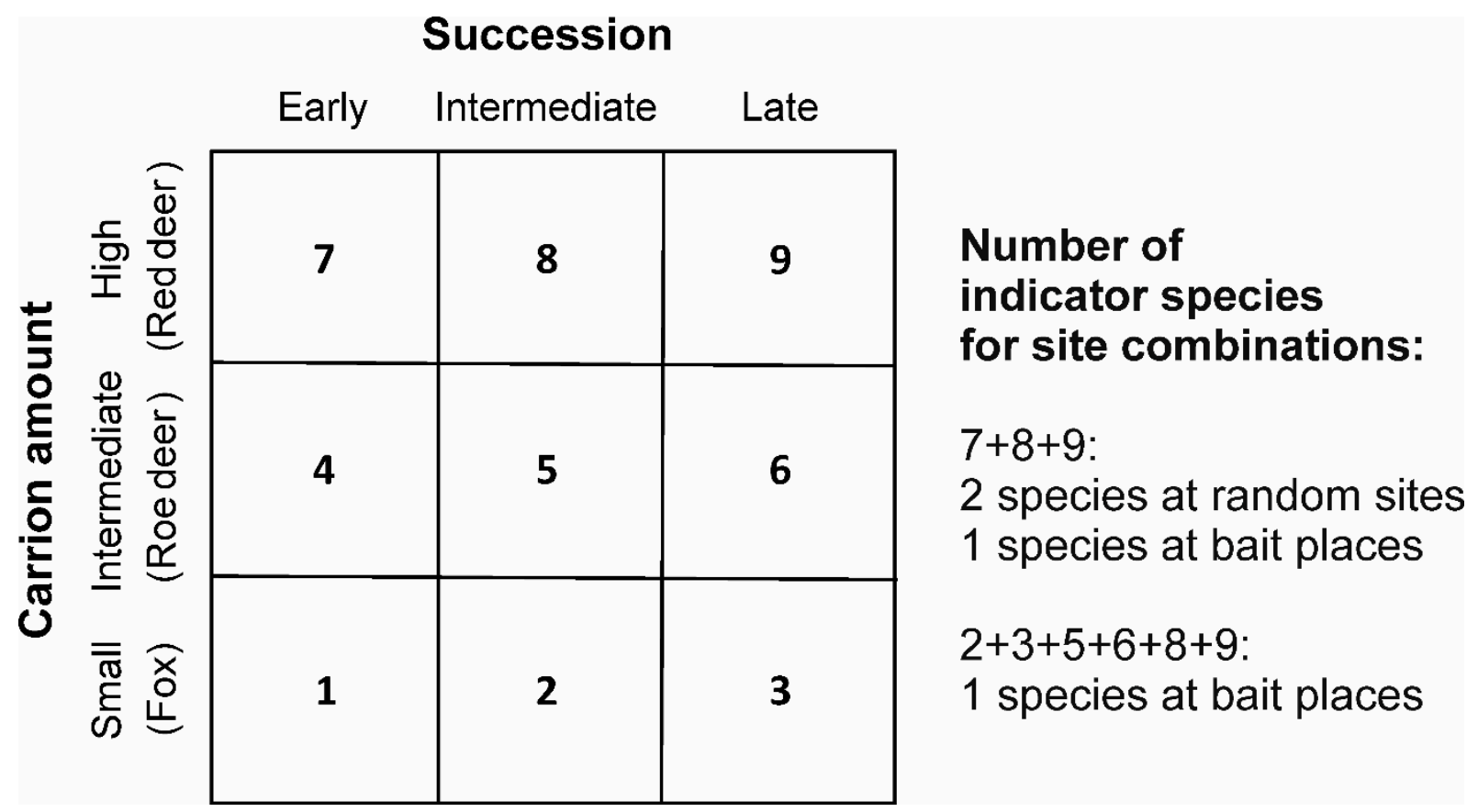

Figure 4. Number of indicator species for different site combinations and their associated site-group matrix used for indicator species analysis. Early = fresh decomposition stage; intermediate = bloated and active decay decomposition stages; late $=$ advanced decay and dry remains decomposition stages.

One geotrupid species (Anoplotrupes stercorosus; IndVal $=0.866 ; \mathrm{p}=0.017$ ) was an indicator species for intermediate (bloated and active decay) and advanced decay and dry stages during carrion decomposition at random sites (Figure 4 and Supplementary Materials Table S4).

\section{Discussion}

We found significant higher necrophilous beetle species diversity at fixed place carcasses, most pronounced with dominant species. Our finding is the opposite reported for vertebrate scavengers at carrion resources $[19,20]$ and thus does not support our vertebrate driven hypothesis of a more diverse insect community at random placed carcasses.

VanLaerhoven [52] stated that increases in abundance or carrion amount (size of carrion resources) should increase the number of trophic levels within local food webs, similar to the carrion associated species diversity. For necrophilous coleopteran taxa, our result of a higher diversity at fixed locations with constantly high carrion placement rates (increasing carrion abundance and mass over time) matches with the statement of VanLaerhoven [52]. In contrast to vertebrate scavenger communities, where the dominant species, the Griffon vulture (Gyps fulvus), arrives earlier and is able to monopolize the carrion resource in predictable conditions, such as fixed locations [20], we assumed that competition with negative effects on visitor diversity at fixed locations would have a minor, negligible or inverse relationship with necrophilous beetle abundance and diversity. Our results show the highest diversity in dominant beetle species during carcass bloated and active decay at fixed locations. Silphidae are part of that dominant species pool (Table 1, Figure 2), are effective predators of fly larvae [53-56], and were well established in high numbers at fixed locations (as part of the local background species pool). There increased abundance can reduce the immense maggot masses on carrion during bloated and active decay (maggot mass dominated stages [31]) by direct consumption. In turn, such direct predatory interactions could structure overall species diversity and carrion community dynamics [52,57]. Moreover, the presence of members of other insect taxa, such as ants and wasps (both Hymenoptera), has frequently been reported to delay colonization of flies 
and change succession and colonization patterns [58-60]. We suggest that a quantitative reduction of substrate degrading maggot masses releases niche space for a more diverse necrophilous beetle community. This also applies to rapid carrion monopolization by large vertebrate scavengers, such as lynx or vultures, leading to soft-tissue removal and thus preventing extended blowfly activity [61,62]. Facilitation (or commensalism) was originally defined by Connell [63] as early colonists (e.g., silphids or avian scavengers are immediately available on site at fixed locations), making the environment (e.g., carcass resource) more suitable for later colonists and is one potential mechanism for succession. These early colonists have been called ecosystem engineers [64].

Regarding carrion volume, Moleón [65] suggested that increased carrion biomass resulting from vertebrate scavenger reductions at carnivore carcasses enables a successional insect community of the remains. This was confirmed by a carnivore carcass avoidancestudy of Muñoz-Lozano [66], showing a well-structured and diverse insect community consisting of necrophages, omnivores, and necrophilous predators and parasitoids. In contrast to the studies of Moleón [65] and Muñoz-Lozano [66], no carnivore carcasses were exposed at our fixed locations, and access by vertebrate scavengers, such as red foxes, pine martens, or Eurasian lynx, to the exposed roe and red deer carcasses took place [21]. However, the bait site situation in the BFNP with regular and year-round carrion supply guarantees a localized increased carrion volume over time despite the vertebrate scavenger visitors. Consequently, besides the above-discussed facilitation hypotheses, a highly diverse successional insect community could be a result of the total carrion volume, commensurate with the results of Moleón [65] and Muñoz-Lozano [66].

Carrion exposition type (random versus fixed), cadaver species (offer of carrion biomass), and decomposition stages of wildlife carcasses revealed characteristic indicator species. We detected two red-listed [51] indicator species for fixed locations, namely the nitidulid species Omosita depressa and the clerid species Necrobia violacea. Necrobia violacea is a carrion associated saprophagous and predaceous beetle [67]. It feeds on dermestid larvae [68] and is characteristic for the long-lasting existence of advanced decay and dry remains [69-71] and therewith associated cadaver decomposition islands (CDIs [72]) as a typical appearance at fixed locations with high carrion turnover rates. Consequently, we suggest the extended highly nutrient-rich (pronounced increase in soil nitrogen concentration and other nutrients, such as calcium, magnesium, and potassium [72]) CDIs at fixed locations provide important refuges for threatened red-listed species, such as $N$. violacea. This is substantiated by the small catching numbers of only one individual at overall 17 random sites compared to 44 specimens at a total of four fixed locations during our trapping campaign in the BFNP, emphasizing the importance of the bait site situation for this beetle species. Haelewaters [71] reported Cleridae as the least abundant during their exposition study of five car-killed roe deer, which are typical random carcasses. Only one specimen was collected during the dry-remains stage [71]. In the Czech Republic, Kočárek [69] collected $N$. violacea as the sole Cleridae species at exposed rat carcasses. Both examples, together with our results, emphasize the importance of fixed feeding sites when considering carrion subsidies as a measure for preserving clerid diversity in a forest ecosystem.

The Nitidulidae family of our second detected red-list indicator species for fixed locations, O. depressa, was reported by Benbow [73] as an indicator taxon for active decay of swine carcasses. This supports our assumption about the importance of a well-established and long-lasting CDI situation for beetle diversity being typical for fixed locations. Furthermore, Saloña [74] reported O. depressa for the first time in the Iberian Peninsula as part of the edaphic fauna after a corpse was removed. They stated that soil-related fauna remaining for days after the removal of a corpse (as very typical for fixed exposition sites; von Hoermann [75], personal observation in the BFNP) could possibly deliver information related to death circumstances during crime scene investigations. In the literature, O. depressa is described as a species living on bones and in dry carcasses [76], both of which are typical long-lasting remains one can encounter at regularly carrion-loaded fixed locations. Omosita 
depressa was also described as very local and scarce sap feeding species in a heavily wooded area in Scotland containing significant amounts of dead wood [77].

In line with our results of two staphylinid species and one Scarabaeidae species as indicative for high carrion biomass, Dekeirsschieter [78] identified O. laqueatus on high carrion biomass (large domestic pig carcasses) during spring in a temperate forest biotope. This underlines the importance of cadaver size for specific necrophilous species of the carrion entomofauna. Interestingly, Vindstad [79] found O. laqueatus in large deadwood biomass as well. After a devastating outbreak of the moth Epirrita autumnata (Lepidoptera: Geometridae) in North Norway, Vindstad [79] identified O. laqueatus as not saproxylic beetle species inside of the vast quantities of deadwood with a significant 7.5-fold higher abundance compared to not affected forest at the periphery of the moth outbreak. The findings of Vindstad [79] and Deikeirsschieter [78] and the result of our study show O. laqueatus as an indicator species for both large deadwood and carrion biomass (red deer and domestic pig carcasses). Oxytelus laqueatus has been recorded in many types of decaying organic matter, even from sap runs [80].

Large maggot masses at large vertebrate carrion (=high cadaver biomass) are preferred feeding sites for necrophilous and predatory staphylinid beetles [31]. Most carrionassociated staphylinid beetles are predators that feed on eggs and larvae of Diptera at active decay and advanced decay stages or comprise saprophagous species feeding on cadaveric fluids and parasitizing dipteran pupae, such as Aleochara curtula $[18,81,82]$. The second staphylinid species we detected as an indicator of high cadaver biomass (carcasses of the large ungulate red deer), P. marginatus, is predatory and polyphagous. It feeds on dipteran eggs, larvae, and even adults [83]. Weithmann [84] found the highest staphylinid beetle abundance in one of the German red deer areas, the Schorfheide-Chorin Biosphere Reserve in Brandenburg. The authors concluded that higher numbers of large vertebrates, such as red deer, may increase the occurrence of large carrion in these forests, generating large dipteran larvae masses as prey for the large-sized and predatory Philonthus species [84]. Accordingly, we detected the Philonthus species P. marginatus as an indicator species for red deer carrion in the red deer area BFNP in Southeast Germany. This emphasizes the importance of high cadaver biomass subsidies (e.g., large ungulate carcasses) for establishing a diverse and highly abundant staphylinid community over time, as confirmed for the vertebrate scavenger diversity as well [21].

As indicative for intermediate (bloated and active decay) and late (advanced decay and dry remains) carrion decomposition stages we detected the geotrupids dung beetle species Anoplotrupes stercorosus. Anoplotrupes stercorosus is a very frequent copronecrophagous forest species and can be encountered in all kinds of dung, on carrion and in old fungi [45,85-87]. Our results concur with those of von Hoermann [36], who detected highest abundance of necrophilous dung beetles in advanced decay stages of exposed piglet cadavers in German forests (including the Hainich National Park in Thuringia), where A. stercorosus was counted as the most abundant species [36]. In line with these results, Jarmusz [88] detected an increase in A. stercorosus numbers during bloated and active decay stages of pig cadaver decomposition in forest habitats in Western Poland, peaking during advanced decay. Such late decomposition stages are characterized by substantial releases of nutrient-rich cadaveric fluids into the underlying soil [72], constituting a highly attractive food source (readily available mixture of nutrients and organic matter) for certain Geotrupidae species [36]. Collectively, these studies and our results support the importance of leaving wildlife carcasses in forest habitats to guarantee the onset and progress of later decomposition stages as an urgent precondition for preserving the diversity of important ecosystem service providers, such as the copronecrophagous dung beetles.

Particularly noticeable in our pitfall traps were the following two rare necrophilous species, the "primitive" carrion beetle Necrophilus subterraneus (Coleoptera: Agyrtidae) with seven individuals at fixed locations (all roe deer carcasses) and one individual at a random site (roe deer carcass) and the false clown beetle Sphaerites glabratus (Coleoptera: 
Sphaeritidae) with six specimens at random sites (five roe deer and one fox carcass) and three individuals at fixed locations (all roe deer carcasses, Table 1).

Necrophilus subterraneus occurs in Central Europe [89] but is not known to be in the Šumava Mountains (the Bohemian Forest, Czech Republic) so far (Růžička [90], personal communication). In the Central European mountains, N. subterraneus is active in summer and can be sometimes collected at carrion or other decomposing material [91]. It is nocturnal and a specialist feeder on snail carcasses (e.g., [92-94]). Necrophilus (Latreille, 1829) comprises five species in the Palearctic region $[95,96]$. In Europe, only N. subterraneus (Dahl, 1807) is present $[95,97]$. Such documented rare polyphagous species at ungulate carrion that is allowed to decompose entirely demonstrates the importance and necessity of regular carrion supply and retention in forest ecosystems. This can be easily achieved by exposing automatically acquired roe deer carcasses from local wildlife-vehicle collisions, as applied in the BFNP.

Furthermore, we collected nine adult individuals of the rare and only partly described (larvae are known only from the description of first instar larvae reared by Nikitsky [98]; eggs and pupae are unknown [99]) the false histerid beetle S. glabratus on roe deer carrion and on a red fox cadaver that was in advanced decay. Sphaeritidae are associated with decomposing organic material, such as carrion, dung, fermenting fruits, fungi, sap of dead or dying trees, and stumps [99]. In Europe, only the species S. glabratus is present [100,101]. For S. glabratus, an environmental association with northern conifer forests, sometimes at high altitudes, has been reported [99,100], which is in accordance with our forested National Park study area. All S. glabratus at our exposed roe deer and fox carcasses were collected along an elevational range from 774 to $880 \mathrm{~m}$ a.s.l. At each of 21 forest plots in an area extending from Danube lowland up to the mountain summits in the Bohemian Forest (overlapping with the same study area we used for our carrion expositions), Farwig [42] installed one trap baited with two carcasses of Mus musculus for attracting and collecting insect scavengers. Consistent with our results, this author trapped a total of four individuals of the uncommon species $S$. glabratus at small rodent carrion, highlighting the high conservation value of the Bohemian Forest ecosystem not only for saproxylic beetles (e.g., References [39,102]), but also for necrophilous beetles. All of these findings clearly show the importance of leaving and additionally providing wildlife carcasses-from small rodents to medium-sized carnivores up to large ungulates-in protected forests, to preserve very rare and threatened beetle species as essential members of the invertebrate part of the necrobiome.

\section{Conclusions}

Our wildlife carrion exposition and insect-trapping study clearly demonstrate the importance of concentrated carcass bait sites compared to random availability, carcass size, and decay stage on the diversity pattern of carrion-associated beetles. The exposure affected insect diversity in a different way than those reported from vertebrates. This implies the necessity of examining all parts of the necrobiome from microbes, insects, and vertebrate scavengers for a more complete understanding of the complexity in carrion visitor diversity. Furthermore, our findings of rare species on such carrion resources emphasize the importance of carrion for biodiversity conservation. Additional studies of the entire necrobiome will allow for general comparisons with communities decomposing other types of necromass, e.g., deadwood, litter, or dung, to support a more general understanding of the community structure and function of all forms of decaying organic matter. 
Supplementary Materials: The following are available online at https:/ / www.mdpi.com/article/10 .3390/insects12050412/s1. Table S1: Carrion exposition scheme in the Bavarian Forest National Park from June till November 2018. Table S2: Asymptotic beetle diversity estimates along with related statistics for Hill numbers $q=0, q=1$, and $q=2$. Table S3: List of 77 species of necrophilous beetles captured at wildlife carcasses, with their indicator value (IndVal), the adjusted $p$-value [1], and the group of sites for which they are characteristic. Significant indicator species are marked in bold. Table S4: List of 57 species of necrophilous beetles captured at wildlife carcasses, with their indicator value (IndVal), the adjusted $p$-value [1], and the group of sites for which they are characteristic (see Figure 4 in the main manuscript for code explanations). Significant indicator species are marked in bold. Table S5: List of 62 species of necrophilous beetles captured at wildlife carcasses, with their indicator value (IndVal), the adjusted $p$-value [1], and the group of sites for which they are characteristic (see Figure 4 in the main manuscript for code explanations; no small (fox) cadavers were exposed at bait places). Significant indicator species are marked in bold.

Author Contributions: Conceptualization, C.v.H., M.H., M.E.B., and J.M.; data curation, C.v.H.; formal analysis, C.v.H. and J.M.; investigation, C.v.H., T.L., and D.S.; methodology, C.v.H.; project administration, C.v.H.; resources, M.H. and J.M.; visualization, C.v.H. and J.M.; writing-original draft, C.v.H.; writing-review and editing, C.v.H., M.E.B., and J.M. All authors have read and agreed to the published version of the manuscript.

Funding: This research received no external funding.

Institutional Review Board Statement: Ethical review and approval were waived for this study, because its protocol did not involve invasive measurements in animals.

Data Availability Statement: The data presented in this study are available on request from the corresponding author or from the Bavarian Forest National Park Administration.

Acknowledgments: We are grateful to the student assistants, volunteers, and colleagues of the Bavarian Forest National Park, namely Jan Philipp Böhm, Kay Hammermeister, Ferdinand Marquardt, Harald Bauer, and Martin Gahbauer, for their great enthusiasm during fieldwork. We thank Robin Dörr for insect presorting. We are grateful to Jörg Salamon and Ulrich Schaffrath for species determination. Finally, we thank Ann-Marie Rottler-Hoermann for graphical illustration.

Conflicts of Interest: The authors declare no conflict of interest.

\section{References}

1. Swift, M.J.; Heal, O.W.; Anderson, J.M. Decomposition in Terrestrial Ecosystems; Blackwell Scientific Publications: Oxford, UK, 1979.

2. Moore, J.C.; Berlow, E.L.; Coleman, D.C.; de Ruiter, P.C.; Dong, Q.; Hastings, A.; Johnson, N.C.; McCann, K.S.; Melville, K.; Morin, P.J.; et al. Detritus, trophic dynamics and biodiversity. Ecol. Lett. 2004, 7, 584-600. [CrossRef]

3. Parmenter, R.R.; MacMahon, J.A. Carrion decomposition and nutrient cycling in a semiarid shrub-steppe ecosystem. Ecol. Monogr. 2009, 79, 637-661. [CrossRef]

4. Barton, P.S.; Cunningham, S.A.; Lindenmayer, D.B.; Manning, A.D. The role of carrion in maintaining biodiversity and ecological processes in terrestrial ecosystems. Oecologia 2013, 171, 761-772. [CrossRef] [PubMed]

5. Benbow, M.E.; Barton, P.S.; Ulyshen, M.D.; Beasley, J.C.; DeVault, T.L.; Strickland, M.S.; Tomberlin, J.K.; Jordan, H.R.; Pechal, J.L. Necrobiome framework for bridging decomposition ecology of autotrophically and heterotrophically derived organic matter. Ecol. Monogr. 2019, 89, e01331. [CrossRef]

6. Gessner, M.O.; Swan, C.M.; Dang, C.K.; McKie, B.G.; Bardgett, R.D.; Wall, D.H.; Hättenschwiler, S. Diversity meets decomposition. Trends Ecol. Evol. 2010, 25, 372-380. [CrossRef]

7. Benbow, M.E.; Receveur, J.P.; Lamberti, G.A. Death and decomposition in aquatic ecosystems. Front. Ecol. Evol. 2020, 8, 17. [CrossRef]

8. Lamberti, G.A.; Levesque, N.M.; Brueseke, M.A.; Chaloner, D.T.; Benbow, M.E. Editorial: Animal mass mortalities in aquatic ecosystems: How common and influential? Front. Ecol. Evol. 2020, 8, 343. [CrossRef]

9. Yang, L.H.; Edwards, K.F.; Byrnes, J.E.; Bastow, J.L.; Wright, A.N.; Spence, K.O. A meta-analysis of resource pulse-consumer interactions. Ecol. Monogr. 2010, 80, 125-151. [CrossRef]

10. Seibold, S.; Hagge, J.; Müller, J.; Gruppe, A.; Brandl, R.; Bässler, C.; Thorn, S. Experiments with dead wood reveal the importance of dead branches in the canopy for saproxylic beetle conservation. For. Ecol. Manag. 2018, 409, 564-570. [CrossRef]

11. Müller, J.; Ulyshen, M.; Seibold, S.; Cadotte, M.; Chao, A.; Bässler, C.; Vogel, S.; Hagge, J.; Weiß, I.; Baldrian, P.; et al. Primary determinants of communities in deadwood vary among taxa but are regionally consistent. Oikos 2020, 129, 1579-1588. [CrossRef] 
12. Braack, L.E.O. Community dynamics of carrion-attendant arthropods in tropical African woodland. Oecologia 1987, 72, 402-409. [CrossRef]

13. Payne, J.A.; King, E.W.; Beinhart, G. Arthropod succession and decomposition of buried pigs. Nature 1968, $219,1180-1181$. [CrossRef]

14. Pechal, J.L.; Crippen, T.L.; Tarone, A.M.; Lewis, A.J.; Tomberlin, J.K.; Benbow, M.E. Microbial community functional change during vertebrate carrion decomposition. PLoS ONE 2013, 8, e79035. [CrossRef]

15. Pechal, J.L.; Benbow, M.E.; Crippen, T.L.; Tarone, A.M.; Tomberlin, J.K. Delayed insect access alters carrion decomposition and necrophagous insect community assembly. Ecosphere 2014, 5, art45. [CrossRef]

16. Bump, J.K.; Peterson, R.O.; Vucetich, J.A. Wolves modulate soil nutrient heterogeneity and foliar nitrogen by configuring the distribution of ungulate carcasses. Ecology 2009, 90, 3159-3167. [CrossRef]

17. Coe, M. The decomposition of elephant carcases in the Tsavo (East) National Park, Kenya. J. Arid Environ. 1978, 1, 71-86. [CrossRef]

18. Benbow, M.E.; Tomberlin, J.K.; Tarone, A.M. Carrion Ecology, Evolution, and Their Applications; CRC Press: Boca Raton, FL, USA, 2015.

19. Wilmers, C.C.; Stahler, D.R.; Crabtree, R.L.; Smith, D.W.; Getz, W.M. Resource dispersion and consumer dominance: Scavenging at wolf-and hunter-killed carcasses in Greater Yellowstone, USA. Ecol. Lett. 2003, 6, 996-1003. [CrossRef]

20. Cortés-Avizanda, A.; Jovani, R.; Carrete, M.; Donázar, J.A. Resource unpredictability promotes species diversity and coexistence in an avian scavenger guild: A field experiment. Ecology 2012, 93, 2570-2579. [CrossRef] [PubMed]

21. Stiegler, J.; Von Hoermann, C.; Müller, J.; Benbow, M.E.; Heurich, M. Carcass provisioning for scavenger conservation in a temperate forest ecosystem. Ecosphere 2020, 11, e03063. [CrossRef]

22. Lai, Y.C.; Liu, Y.R. Noise promotes species diversity in nature. Phys. Rev. Lett. 2005, 94, 038102. [CrossRef]

23. Wilmers, C.C.; Crabtree, R.L.; Smith, D.W.; Murphy, K.M.; Getz, W.M. Trophic facilitation by introduced top predators: Grey wolf subsidies to scavengers in Yellowstone National Park. J. Anim. Ecol. 2003, 72, 909-916. [CrossRef]

24. Schoenly, K.; Reid, W. Dynamics of heterotrophic succession in carrion arthropod assemblages: Discrete seres or a continuum of change? Oecologia 1987, 73, 192-202. [CrossRef]

25. Boulton, A.J.; Lake, P.S. Dynamics of heterotrophic succession in carrion arthropod assemblages. Oecologia 1988, 76, 477-480. [CrossRef]

26. Schoenly, K.G.; Reid, W. Dynamics of heterotrophic succession in carrion revisited. Oecologia 1989, 79, 140-142. [CrossRef] [PubMed]

27. Moura, M.O.; Monteiro-Filho, E.L.d.A.; de Carvalho, C.J.B. Heterotrophic succession in carrion arthropod assemblages. Brazilian Arch. Biol. Technol. 2005, 48, 477-486. [CrossRef]

28. Matuszewski, S.; Bajerlein, D.; Konwerski, S.; Szpila, K. Insect succession and carrion decomposition in selected forests of Central Europe. Part 3: Succession of carrion fauna. Forensic Sci. Int. 2011, 207, 150-163. [CrossRef] [PubMed]

29. Mondor, E.B.; Tremblay, M.N.; Tomberlin, J.K.; Benbow, E.M.; Tarone, A.M.; Crippen, T.L. The ecology of carrion decomposition. Nat Educ Knowl. 2012, 3, 21.

30. Fiedler, A.; Halbach, M.; Sinclair, B.; Benecke, M. What is the edge of a forest? A diversity analysis of adult Diptera found on decomposing piglets inside and on the edge of a Western German woodland inspired by a courtroom question. Entomol. Heute 2008, 20, 173-191.

31. Goff, M.L. Early post-mortem changes and stages of decomposition in exposed cadavers. Exp. Appl. Acarol. 2009, 49, 21-36. [CrossRef]

32. Introna, F.; Campobasso, C.P. Forensic dipterology. In Contributions to a Manual of Palaearctic Diptera, General and Applied Dipterology; Papp, L., Darvas, B., Eds.; Science Herald: Budapest, Hungary, 2000; Volume 1, pp. 793-846.

33. von Hoermann, C.; Ruther, J.; Ayasse, M. The attraction of virgin female hide beetles (Dermestes maculatus) to cadavers by a combination of decomposition odour and male sex pheromones. Front. Zool. 2012, 9, 1-11. [CrossRef] [PubMed]

34. Amendt, J.; Krettek, R.; Zehner, R. Forensic entomology. Naturwissenschaften 2004, 91, 51-65. [CrossRef]

35. Strümpher, W.P.; Farrell, J.; Scholtz, C.H. Trogidae (Coleoptera: Scarabaeoidea) in forensic entomology: Occurrence of known and new species in Queensland, Australia. Austral Entomol. 2014, 53, 368-372. [CrossRef]

36. von Hoermann, C.; Weithmann, S.; Deißler, M.; Ayasse, M.; Steiger, S. Forest habitat parameters influence abundance and diversity of cadaver-visiting dung beetles in Central Europe. R. Soc. Open Sci. 2020, 7, 191722. [CrossRef]

37. Heurich, M.; Beudert, B.; Rall, H.; Křenová, Z. National parks as model regions for interdisciplinary long-term ecological research: The Bavarian Forest and Šumavá National Parks underway to transboundary ecosystem research. In Long-Term Ecological Research; Müller, F., Baessler, C., Schubert, H., Klotz, S., Eds.; Springer: Dordrecht, The Netherlands, 2010; pp. 327-344.

38. Cailleret, M.; Heurich, M.; Bugmann, H. Reduction in browsing intensity may not compensate climate change effects on tree species composition in the Bavarian Forest National Park. For. Ecol. Manag. 2014, 328, 179-192. [CrossRef]

39. Seibold, S.; Büche, B.; Szallies, A.; Müller, J. Neue Käfernachweise im Nationalpark Bayerischer Wald im Rahmen von Totholzexperimenten (Insecta: Coleoptera). Beiträge zur Bayerischen Entomofaunistik 2017, 17, 1-17. 
40. Möst, L.; Hothorn, T.; Müller, J.; Heurich, M. Creating a landscape of management: Unintended effects on the variation of browsing pressure in a national park. For. Ecol. Manag. 2015, 338, 46-56. [CrossRef]

41. Müller, J.; Brandl, R. Assessing biodiversity by remote sensing in mountainous terrain: The potential of LiDAR to predict forest beetle assemblages. J. Appl. Ecol. 2009, 46, 897-905. [CrossRef]

42. Farwig, N.; Brandl, R.; Siemann, S.; Wiener, F.; Müller, J. Decomposition rate of carrion is dependent on composition not abundance of the assemblages of insect scavengers. Oecologia 2014, 175, 1291-1300. [CrossRef]

43. Dekeirsschieter, J.; Verheggen, F.J.; Haubruge, E.; Brostaux, Y. Carrion beetles visiting pig carcasses during early spring in urban, forest and agricultural biotopes of Western Europe. J. Insect. Sci. 2011, 11, 73. [CrossRef]

44. von Hoermann, C.; Jauch, D.; Kubotsch, C.; Reichel-Jung, K.; Steiger, S.; Ayasse, M. Effects of abiotic environmental factors and land use on the diversity of carrion-visiting silphid beetles (Coleoptera: Silphidae): A large scale carrion study. PLoS ONE 2018, 13, e0196839. [CrossRef]

45. Matuszewski, S.; Bajerlein, D.; Konwerski, S.; Szpila, K. Insect succession and carrion decomposition in selected forests of Central Europe. Part 2: Composition and residency patterns of carrion fauna. Forensic Sci. Int. 2010, 195, 42-51. [CrossRef]

46. R: A Language and Environment for Statistical Computing (Wien: R Foundation for Statistical Computing). Available online: https:/ / www.R-project.org/ (accessed on 10 October 2020).

47. Hill, M.O. Diversity and evenness: A unifying notation and its consequences. Ecology 1973, 54, 427-432. [CrossRef]

48. Chao, A.; Gotelli, N.J.; Hsieh, T.C.; Sander, E.L.; Ma, K.H.; Colwell, R.K.; Ellison, A.M. Rarefaction and extrapolation with Hill numbers: A framework for sampling and estimation in species diversity studies. Ecol. Monogr. 2014, 84, 45-67. [CrossRef]

49. Hsieh, T.C.; Ma, K.H.; Chao, A. iNEXT: An R package for interpolation and extrapolation of species diversity (Hill numbers). Methods Ecol. Evol. 2016, 7, 1451-1456. [CrossRef]

50. De Cáceres, M.; Legendre, P. Associations between species and groups of sites: Indices and statistical inference. Ecology 2009, 90, 3566-3574. [CrossRef]

51. Esser, J. Rote Liste und Gesamtartenliste der Kapuzinerkäferartigen (Bostrichoidea), Buntkäferartigen (Cleroidea), Plattkäferartigen (Cucujoidea), Schnellkäferartigen (Elateroidea), Werftkäferartigen (Lymexyloidea) und Schwarzkäferartigen (Tenebrioidea); Universitätsverlag der TU Berlin: Berlin, Germany, 2017.

52. VanLaerhoven, S.L.; Benbow, M.E.; Tomberlin, J.K.; Tarone, A.M. Modeling species interactions within carrion food webs. In Carrion Ecology, Evolution, and Their Applications; Benbow, M.E., Tomberlin, J.K., Tarone, A.M., Eds.; CRC: Boca Raton, FL, USA, 2015; pp. 231-245.

53. Pukowski, E. Ökologische Untersuchungen an Necrophorus F. Z. Morphol. Okol. Tiere 1933, 27, 518-586. [CrossRef]

54. Kentner, E.; Streit, B. Temporal distribution and habitat preference of congeneric insect species found at rat carrion. Pedobiologia 1990, 34, 347-359.

55. Scott, M.P. The ecology and behavior of burying beetles. Annu. Rev. Entomol. 1998, 43, 595-618. [CrossRef]

56. Matuszewski, S.; Bajerlein, D.; Konwerski, S.; Szpila, K. An initial study of insect succession and carrion decomposition in various forest habitats of Central Europe. Forensic Sci. Int. 2008, 180, 61-69. [CrossRef]

57. Kadlec, J.; Mikatova, S.; Maslo, P.; Sipkova, H.; Sipek, P.; Sladecek, F.X.J. Delaying insect access alters community composition on small carrion: A quantitative approach. Entomol. Exp. Appl. 2019, 167, 729-740. [CrossRef]

58. Anderson, G.S. Factors that influence insect succession on carrion. In Forensic Entomology: The Utility of Arthropods in Legal Investigations; Byrd, J., Castner, E., Eds.; CRC Press: Boca Raton, FL, USA, 2009; pp. 201-250.

59. Anderson, G.S. Forensic entomology. In Forensic Science, an Introduction to Scientific and Investigative Techniques; James, S.H., Nordby, J., Eds.; CRC Press: Boca Raton, FL, USA, 2009; pp. 137-165.

60. Lindgren, N.K.; Bucheli, S.R.; Archambeault, A.D.; Bytheway, J.A. Exclusion of forensically important flies due to burying behavior by the red imported fire ant (Solenopsis invicta) in southeast Texas. Forensic Sci. Int. 2011, 204, e1-e3. [CrossRef]

61. DeVault, T.L.; Rhodes, O.E., Jr.; Shivik, J.A. Scavenging by vertebrates: Behavioral, ecological, and evolutionary perspectives on an important energy transfer pathway in terrestrial ecosystems. Oikos 2003, 102, 225-234. [CrossRef]

62. van den Heever, L.; Thompson, L.J.; Bowerman, W.W.; Smit-Robinson, H.; Shaffer, L.J.; Harrell, R.M.; Ottinger, M.A. Reviewing the role of vultures at the human-wildlife-livestock disease interface: An African perspective. J. Raptor Res. 2021, 55. [CrossRef]

63. Connell, J.H.; Slatyer, R.O. Mechanisms of succession in natural communities and their role in community stability and organization. Am. Nat. 1977, 111, 1119-1144. [CrossRef]

64. Jones, C.G.; Lawton, J.H.; Shachak, M. Organisms as ecosystem engineers. In Ecosystem Management; Samson, F.B., Knopf, F.L., Eds.; Springer: New York, NY, USA, 1994; pp. 130-147.

65. Moleón, M.; Martínez-Carrasco, C.; Muellerklein, O.C.; Getz, W.M.; Muñoz-Lozano, C.; Sánchez-Zapata, J.A. Carnivore carcasses are avoided by carnivores. J. Anim. Ecol. 2017, 86, 1179-1191. [CrossRef]

66. Muñoz-Lozano, C.; Martín-Vega, D.; Martínez-Carrasco, C.; Sánchez-Zapata, J.A.; Morales-Reyes, Z.; Gonzálvez, M.; Moleón, M. Avoidance of carnivore carcasses by vertebrate scavengers enables colonization by a diverse community of carrion insects. PLoS ONE 2019, 14, e0221890. [CrossRef]

67. Opitz, W.; Arnett, J.R.H. Cleridae Latreille 1804. In American Beetles, Polyphaga: Scarabaeoidea through Curculionoidea; Arnett, R.H., Thomas, M.C., Skelley, P.E., Frank, J.H., Eds.; CRC Press: Boca Raton, FL, USA, 2002; Volume 2, pp. $267-280$. 
68. Knull, J.N. The checkered beetles of Ohio (Coleoptera: Cleridae). Ohio Biol. Surv. Bull. 1951, 8, 268-350.

69. Kočárek, P. Decomposition and Coleoptera succession on exposed carrion of small mammal in Opava, the Czech Republic. Eur. J. Soil Biol. 2003, 39, 31-45. [CrossRef]

70. Anton, E.; Niederegger, S.; Beutel, R.G. Beetles and flies collected on pig carrion in an experimental setting in Thuringia and their forensic implications. Med. Vet. Entomol. 2011, 25, 353-364. [CrossRef]

71. Haelewaters, D.; Vanpoucke, S.; Raes, D.; Krawczynski, R. On carrion-associated beetles in the Sonian Forest (Belgium): Observations on five deer carcasses. Bull. Société R. Belge d'Entomologie 2015, 151, 25-33.

72. Carter, D.O.; Yellowlees, D.; Tibbett, M. Cadaver decomposition in terrestrial ecosystems. Naturwissenschaften 2007, 94, 12-24. [CrossRef]

73. Benbow, M.E.; Lewis, A.J.; Tomberlin, J.K.; Pechal, J.L. Seasonal necrophagous insect community assembly during vertebrate carrion decomposition. J. Med. Entomol. 2013, 50, 440-450. [CrossRef]

74. Saloña, M.I.; Moraza, M.L.; Carles-Tolrá, M.; Iraola, V.; Bahillo, P.; Yélamos, T.; Outerelo, R.; Alcaraz, R. Searching the soil: Forensic importance of edaphic fauna after the removal of a corpse. J. Forensic Sci. 2010, 55, 1652-1655. [CrossRef]

75. von Hoermann, C.; (Bavarian Forest National Park Administration, Grafenau, Bavaria, Germany). Personal communication, 2018.

76. Koch, K. Die Käfer Mitteleuropas. Ökologie Band 2; Goecke und Evers Verlag: Krefeld, Germany, 1989.

77. Philp, B.; Hamlin, I.; Lavery, A. Insects and arachnids of Ardeer, North Ayrshire, Scotland. Glas. Nat. 2020, 27. [CrossRef]

78. Dekeirsschieter, J.; Frederick, C.; Verheggen, F.J.; Drugmand, D.; Haubruge, E. Diversity of forensic rove beetles (Coleoptera, Staphylinidae) associated with decaying pig carcass in a forest biotope. J. Forensic Sci. 2013, 58, 1032-1040. [CrossRef]

79. Vindstad, O.P.L.; Schultze, S.; Jepsen, J.U.; Biuw, M.; Kapari, L.; Sverdrup-Thygeson, A.; Ims, R.A. Numerical responses of saproxylic beetles to rapid increases in dead wood availability following geometrid moth outbreaks in sub-arctic mountain birch forest. PLoS ONE 2014, 9, e99624. [CrossRef] [PubMed]

80. Buckland, P.I.; Buckland, P.C. BugsCEP: Coleopteran Ecology Package (Software); NOAA/NCDC Paleoclimatology Program: Boulder, CO, USA, 2006.

81. Koch, K. Die Käfer Mitteleuropas. Ökologie Band 1; Goecke und Evers Verlag: Krefeld, Germany, 1989.

82. Peschke, K.; Friedrich, P.; Kaiser, U.; Franke, S.; Francke, W. Isopropyl (Z9)-hexadecenoate as a male attractant pheromone from the sternal gland of the rove beetle Aleochara curtala (Coleoptera: Staphylinidae). Chemoecology 1999, 9, 47-54. [CrossRef]

83. Lipkow, E. Habits of Philonthus species and other Staphylinidae (Coleoptera) in dung. Drosera 1982, 1, 47-54.

84. Weithmann, S.; Kuppler, J.; Degasperi, G.; Steiger, S.; Ayasse, M.; von Hoermann, C. Local and landscape effects on carrionassociated rove beetle (Coleoptera: Staphylinidae) communities in German forests. Insects 2020, 11, 828. [CrossRef]

85. von Lengerken, H. Die Brutfürsorge- und Brutpflegeinstinkte der Käfer; Akademische Verlagsgesellschaft Geest und Portig K.G.: Leipzig, Germany, 1954.

86. Teichert, M. Nahrungsspeicherung von Geotrupes vernalis L. und Geotrupes stercorosus Scriba (Coleopt. Scarab.). Wiss. Z. Martin-Luther-Univ. Halle-Wittenb. 1956, 5, 669-672.

87. Byk, A.; Semkiw, P. Habitat preferences of the forest dung beetle Anoplotrupes stercorosus (Scriba, 1791) (Coleoptera: Geotrupidae) in the Białowieża Forest. Acta Sci. Pol. Silvarum Colendarum Ratio Ind. Lignaria 2010, 9, 17-28.

88. Jarmusz, M.; Bajerlein, D. Anoplotrupes stercorosus (Scr.) and Trypocopris vernalis (L.) (Coleoptera: Geotrupidae) visiting exposed pig carrion in forests of Central Europe: Seasonality, habitat preferences and influence of smell of decay on their abundances. Entomol. Gen. 2015, 35, 213-228. [CrossRef]

89. Růžička, J.; Jakubec, P. Icones Insectorum Europae Centralis. Coleoptera: Agyrtidae, Silphidae. Folia Heyrovskiana, Series B 2016, $26,1-17$.

90. Růžička, J.; (Czech University of Life Sciences Prague, Prague, Czech Republic). Personal communication, 2021.

91. Newton, A.F. Review of Agyrtidae (Coleoptera), with a new genus and species from New Zealand. Annal. Zool. 1997, 47, 111-156.

92. Rade, E. Necrophilus subterraneus Dej. und andere Käfer des Göttinger Gebietes 1893. Entomol. Nachr. 1893, 19, 357-363.

93. Zwick, P. Die Jugendstadien des Käfers Necrophilus subterraneus (Coleoptera: Silphidae: Agyrtinae). Beiträge Naturkd. Osthessen 1981, 17, 133-140.

94. Schawaller, W. Die Gattung Necrophilus Latreille 1829 im Himalaya (Insecta: Coleoptera: Agyrtidae). Senckenb. Biol. 1986, 66, 311-319.

95. Růžička, J. Agyrtidae. In Catalogue of Palaearctic Coleoptera. Hydrophiloidea - Staphylinoidea, Revised and Updated ed.; Löbl, I., Löbl, D., Eds.; Brill: Leiden, The Nederlands; Boston, MA, USA, 2015; Volume 2/1, pp. 5, 177-180.

96. Newton, A.F. StaphBase: Staphyliniformia world catalog database (version January 2021). In Species $2000 \mathcal{E}$ ITIS Catalogue of Life, 20th February 2019; Roskov, Y., Ower, G., Orrell, T., Nicolson, D., Bailly, N., Kirk, P.M., Bourgoin, T., DeWalt, R.E., Decock, W., Nieukerken, E., et al., Eds.; Naturalis: Leiden, The Nederlands, 2021; Available online: www.catalogueoflife.org/col (accessed on 18 March 2021).

97. Růžička, J.; Puetz, A. New species and new records of Agyrtidae (Coleoptera) from China, India, Myanmar, Thailand and Vietnam. Acta Entomol. Musei Natl. Pragae 2009, 49, 631-650.

98. Nikitsky, N.B. Morfologia lichinki Sphaerites glabratus F. I filogenia Histeroidea. Zool. Zhurnal. 1976, 55, 531-537.

99. Newton, A.F. 13.1 Sphaeritidae Shuckard, 1839. In Handbook of Zoology, Arthropoda: Insecta. Coleoptera, Beetles. Morphology and Systematics (Archostemata, Adephaga, Myxophaga, Polyphaga Partim); Beutel, R.G., Leschen, R.A.B., Eds.; Walter de Gruyter: Berlin, Germany, 2016; Volume 1, pp. 274-277. 
100. Lackner, T. Coleoptera: Sphaeritidae, Histeridae. Folia Heyrovskyana Ser. B 2015, 23, 1-33.

101. Löbl, I. Sphaeritidae. In Catalogue of Palaearctic Coleoptera. Hydrophiloidea-Staphylinoidea, Revised and Updated ed.; Löbl, I., Löbl, D., Eds.; Brill: Leiden, The Nederlands; Boston, MA, USA, 2015; Volume 2/1, p. 76.

102. Thorn, S.; Bässler, C.; Svoboda, M.; Müller, J. Effects of natural disturbances and salvage logging on biodiversity-lessons from the Bohemian Forest. For. Ecol. Manag. 2017, 388, 113-119. [CrossRef] 